
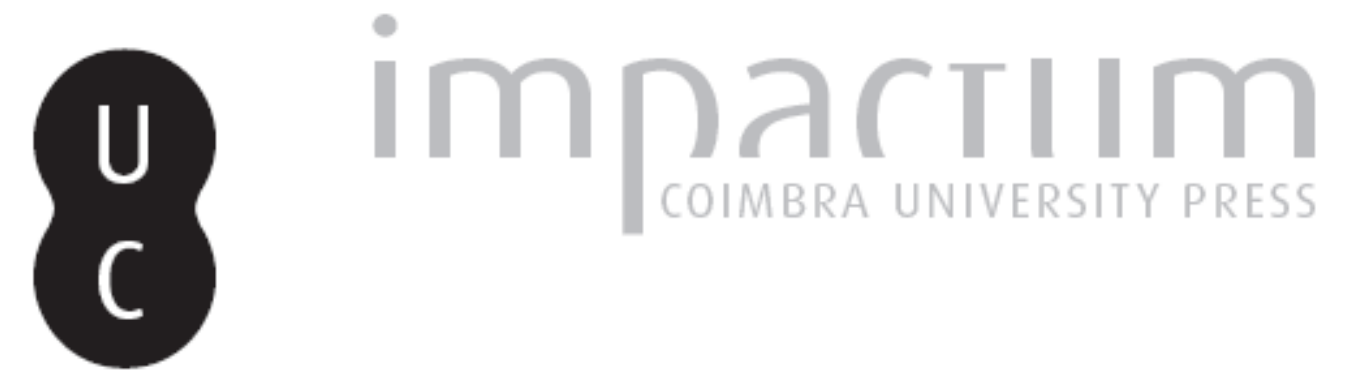

\title{
Arqueologia urbana em Coimbra: um testemunho na Reitoria da Universidade
}

\author{
Autor(es): $\quad$ Filipe, Sónia
}

Publicado por: Faculdade de Letras da Universidade de Coimbra

URL persistente:

URI:http://hdl.handle.net/10316.2/37735

DOI:

DOI:http://dx.doi.org/10.14195/1647-8657_45_18

Accessed : $\quad$ 26-Apr-2023 10:43:04

A navegação consulta e descarregamento dos títulos inseridos nas Bibliotecas Digitais UC Digitalis, UC Pombalina e UC Impactum, pressupõem a aceitação plena e sem reservas dos Termos e Condições de Uso destas Bibliotecas Digitais, disponíveis em https://digitalis.uc.pt/pt-pt/termos.

Conforme exposto nos referidos Termos e Condições de Uso, o descarregamento de títulos de acesso restrito requer uma licença válida de autorização devendo o utilizador aceder ao(s) documento(s) a partir de um endereço de IP da instituição detentora da supramencionada licença.

Ao utilizador é apenas permitido o descarregamento para uso pessoal, pelo que o emprego do(s) título(s) descarregado(s) para outro fim, designadamente comercial, carece de autorização do respetivo autor ou editor da obra.

Na medida em que todas as obras da UC Digitalis se encontram protegidas pelo Código do Direito de Autor e Direitos Conexos e demais legislação aplicável, toda a cópia, parcial ou total, deste documento, nos casos em que é legalmente admitida, deverá conter ou fazer-se acompanhar por este aviso.

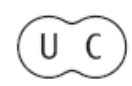




\section{CONIMBRIGA}

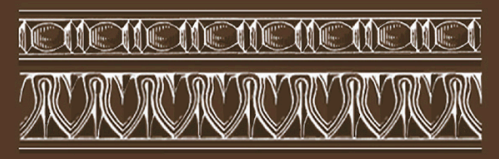

INSTITUTO DE ARQUEOLOGIA

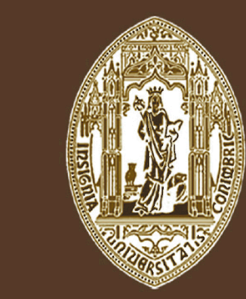

VOLUME XLV - 2006

FACULDADE DE LETRAS UNIVERSIDADE DE COIMBRA 
SóNIA FILIPE

Arqueóloga. Reitoria da Universidade de Coimbra

\author{
ARQUEOLOGIA URBANA EM COIMBRA: \\ UM TESTEMUNHO NA REITORIA DA UNIVERSIDADE \\ "Conimbriga" XLV (2006) p. 337-357
}

Resumo: 1. A actividade arqueológica na Reitoria da Universidade de Coimbra, iniciou-se no Verão de 2000 com a primeira campanha de escavações arqueológicas no Pátio das Escolas. Os resultados daí advindos, a necessidade de continuar os trabalhos e a programação de uma intenção recente de candidatar parte dos espaços universitários a Património Mundial, motivaram a constituição de uma pequena equipa de trabalho, que tem actuado, de forma sistemática e contínua, desde então. 2. Sendo Coimbra uma cidade com ocupação humana sedimentada há, pelo menos, dois milénios, a actividade desenvolvida reflecte naturalmente este palimpsesto ocupacional.

3. Das diferentes acções já realizadas, destacam-se as intervenções no Pátio das Escolas, no Colégio da Trindade e no Laboratório Chimico, todos situados no Pólo I da Universidade de Coimbra, e cujos resultados prévios apontam no sentido de um significativo património arqueológico que, aos poucos, se vai revelando, numa diacronia ocupacional que se estende do período romano (se bem que com frustres testemunhos de um passado mais recuado) até à contemporaneidade.

SUmmary: 1 . The archaeological activity developed by the Reitoria of the University of Coimbra began in the summer of 2000 with the first excavation of Pátio das Escolas. The results of this initiative and the necessity to continue this work, as well as the recent intention to candidate part of the university spaces to World Heritage, were strong motives for the creation of a small team, which has been systematically proceeding since then.

2. As the result of Coimbra's human occupation for, at least, the past two millenniums, the product of the archaeological activity developed naturally reflects this evolution. 
3. Among the several excavations already performed, this article focus the interventions in Pátio das Escolas, Colégio da Trindade and Laboratório Químico, all situated in the centre of the University of Coimbra. Their preliminary results seam to attest the presence of a significant archaeological patrimony, which we are progressively disclosing, revealing a diachronic occupation from the Roman period (despite certain traces of more ancient times) until our days. 


\section{ARQUEOLOGIA URBANA EM COIMBRA: \\ UM TESTEMUNHO NA REITORIA DA UNIVERSIDADE 1}

1. A Universidade de Coimbra é detentora de um vastíssimo património histórico, artístico, literário e construído, consolidado ao longo de sete séculos de memórias. A este acresce o património arqueológico, há muito suspeitado, mas que vai agora sendo, aos poucos, revelado, à medida que, na história multissecular dos espaços e edifícios, vão sendo acrescentadas novas abordagens de conhecimento, pela programação de intervenções arqueológicas, realizadas em meio urbano, e reflectindo o palimpsesto ocupacional que a colina coimbrã comporta.

A actividade arqueológica na Reitoria da Universidade de Coimbra iniciou-se no Verão de 2000 com a primeira campanha de escavações arqueológicas no Pátio das Escolas, através de um projecto pluridisciplinar coordenado pelos Prof. Doutores Helena Catarino (Arqueologia) e António Filipe Pimentel (História de Arte). Os resultados daí advindos, a necessidade de continuar os trabalhos e a programação de uma intenção recente de candidatar parte dos espaços universitários a Património Mundial da Humanidade, motivaram a constituição de uma pequena equipa de trabalho, que coordenamos, que tem actuado desde então.

Nesta pequena reflexão pretendemos, acima de tudo, possibilitar uma pequena visita aos últimos cinco anos da actividade arqueológica desenvolvida na e pela Reitoria da Universidade de Coimbra.

Para além do projecto de intervenção arqueológica no Pátio das Escolas, o mais emblemático, porque primeiro e no coração da univer-

1 Este artigo segue a estrutura da comunicação proferida no $50 .^{\circ}$ aniversário do Instituto de Arqueologia da Universidade de Coimbra - Dia do Antigo Estudante: Percursos e projectos de antigos estudantes do Instituto de Arqueologia, a 18 de Abril de 2005 . 
sidade, outros trabalhos arqueológicos têm sido por nós realizados, dos quais destacamos: acompanhamento arqueológico da implantação de valas para o parque de estacionamento (dir. dos trabalhos de Helena Catarino, com participação de Sónia Filipe e Ana Revez) no Largo da Porta Férrea; escavação arqueológica no edifício da Casa das Caldeiras; acompanhamento arqueológico, prospecções arqueológicas e geofísicas (com colaboração de Paulo Morgado) e avaliação de impactes nos trabalhos de implantação do Pólo III da Universidade na Quinta de Santa Comba; trabalhos arqueológicos prévios, acompanhamento e diversas campanhas de escavações no Colégio da Trindade (em co-direcção técnico-científica com Helena Catarino e Vera Santos); acompanhamento arqueológico da remodelação de uma pequena parte do Colégio de Jesus; trabalhos arqueológicos para a instalação/remodelação da rede de rega do Jardim Botânico; escavações arqueológicas prévias e estudos de arqueologia a cota positiva no Laboratório Chimico e sua envolvente.

Destas intervenções iremos abordar mais pormenorizadamente apenas três que, pela sua importância ao nível da implantação no espaço territorial de Coimbra, e/ou pela relevância dos seus achados merecem, nesta fase, uma reflexão um pouco mais alargada: o Pátio das Escolas, o Colégio da Trindade e o Laboratório Chimico.

2. Tal como facilmente constatamos, as diferentes intervenções sumariamente referenciadas, localizam-se na Alta de Coimbra, berço da ocupação urbana, desde que era conhecida como Aeminium.

De facto, desde finais do século XIX que a coincidência da localização de Aeminium com Coimbra é inequívoca. ${ }^{2}$

A estrutura urbana desta cidade foi-se moldando às irregularidades topográficas, o que lhe conferiu uma posição estratégica de relevo no cimo de um morro com vertentes escarpadas. Muito falta ainda conhecer do seu urbanismo. Terá sido certamente fundada a partir de um núcleo pré-romano que ocuparia sensivelmente a área da actual Alta Universitária; o próprio topónimo da cidade assim o indica (FIGUEIREDO 1886 256). Aguarda-se, no entanto, constatação arqueológica de uma ocupação humana neste espaço para este período. O vestígio mais an-

2 Depois da descoberta da "inscrição honorífica comemorando Constâncio Cloro dedicada pela civitas Aeminiensis" na demolição de uma casa na Couraça dos Apóstolos (MANTAS 1992 487).

Conimbriga, 45 (2006) 337-357 
tigo encontrado na Alta corresponde a uma ponta de seta calcolítica que foi exumada aquando das primeiras escavações realizadas na Alcáçova da cidade (MANTAS 1992 489). Mais recentemente, durante a segunda e terceira campanhas de escavação no Pátio da Universidade, foram identificados mais dois líticos que poderão pertencer igualmente a este período. Ainda durante estes trabalhos, foram identificados alguns alinhamentos de muros, muito destruídos, que poderão, eventualmente, corresponder a vestígios de estruturas da Idade do Ferro, indiciando assim uma ocupação proto-histórica no morro hoje ocupado pela Universidade. O facto de se encontrarem só ao nível dos alicerces, cortados por estruturas posteriores, dificulta de momento a atribuição de uma cronologia mais precisa.

Aeminium exerceria funções de capitalidade enquanto sede de um território adstrito - capital de civitas -, e importante ponto viário caput viarium -, com a passagem da via Olisipo-Bracara sobre a cidade. Acresce ainda a fulcral importância da sua posição de domínio face ao Mondego. De Coimbra partia ainda uma via que fazia a ligação com o interior, em direcção a Bobadela (MANTAS 1996 615).

Para a sua ascensão a capital de civitas foram com certeza mais importantes as vantagens de posição que possuía do que uma eventual importância do oppidum preexistente (ALARCÃo 1992 88). Basta observar a implantação da cidade na paisagem para verificar que estamos na presença de uma cidade-acrópole, com um perfeito domínio sobre o rio que lhe corre na base. O melhor ponto para transpor o Mondego far-se-ia "no ponto onde o vale do rio se estrangulava entre os morros vizinhos, e esse era justamente marcado por uma linha que reunisse o sopé do cabeço de Santa Clara com o da antiga Aeminium" (GIRÃo 1943 79). Aliás, "todas as cidades capitais se situam sobre o percurso das referidas estradas (grandes eixos urbanos) ou dos seus ramais principais" (MANTAS 1998 364/365).

A relação da cidade com os eixos de comunicação, viários e fluviais, permitiu a sua génese, consolidou-a e garantiu-lhe sobrevivência em diferentes fases da construção do nosso espaço territorial.

Desta forma, o território centralizado na cidade de Aeminium reuniu condições de excelência para o seu desenvolvimento durante o período romano e sequentes. Coimbra surge assim como "cidadeponte", como bem classificou, a partir da análise da fotografia aérea, Vasco Mantas (ibid, 1996 615; 1992 493).

Sabemos que a Antiguidade tardia corresponde a um momento de elevação desta cidade à dignidade episcopal, com a transferência da 
sede de bispado de Conimbriga para Aeminium. A este momento devem ter correspondido certamente importantes remodelações na cidade, agora do bispo de Conimbriga, de forma a desempenhar as novas funções. Este factor deve ter contribuído para um dinamismo suplementar nas suas relações com o poder central, como atestam as cunhagens régias no período visigótico. Coimbra torna-se sede de um vasto território, compreendido entre Tomar (paróquia de Sancta Maria de Selio) e Gaia (paróquia de Portucale Castrum Antiquum). O período visigótico materializa, em Coimbra como noutros territórios, a territorialização da fé.

Serão os muçulmanos os responsáveis pela alteração do nome deste centro urbano. Do período de dominação islâmica, o testemunho mais importante até agora identificado é a estrutura do Alcácer da cidade. $^{3}$

Fernando Magno conquista-a definitivamente aos muçulmanos em 1064. A cidade passa a denominar-se Colimbria e uma nova etapa se inicia, até ao momento em que, podemos afirmar, se dá uma (re)fundação deste espaço urbano, bem como uma especialização que não mais perderá: o berço da universidade portuguesa.

Aeminium, passa a Eminio, depois a Qulumryia, Colimbria e, finalmente, Coimbra, iniciando-se um novo momento na história desta cidade com o alvor da Idade Média.

Deixaremos, para análise ulterior, o reconhecimento e estudo dos vestígios de urbanismo desta cidade, uma vez que não se trata do tema central desta reflexão.

3. Deste breve percurso pela evolução da ocupação urbana de Coimbra, facilmente se depreende que, programar ou executar qualquer intervenção arqueológica no seu interior seja sinónimo de intervir num espaço complexamente estratificado, com amplas diacronias de ocupação. Aliás, esta é a realidade de qualquer meio urbano.

A intervenção arqueológica em meio urbano procura reconstruir o meio ambiente, natural e antropizado, onde determinadas acções humanas tiveram lugar. Por arqueologia urbana podemos entender o estudo que procura recuperar fragmentos dispersos do passado das comunidades humanas em determinado espaço e sua interligação, ainda que esses

3 Sobre Coimbra no período compreendido entre a conquista de 714/715 e 1064, veja-se, por outros, CATARINO e FILIPE 2005.

Conimbriga, 45 (2006) 337-357 
testemunhos estejam dispersos na malha urbana actual e se apresentem descontinuados no espaço.

É esta a perspectiva que vai nortear a pequena "visita" a três projectos de investigação arqueológica em curso em espaços propriedade da Reitoria da Universidade de Coimbra que faremos de seguida.

a) Em primeiro lugar, iremos abordar a intervenção arqueológica no Pátio da Universidade de Coimbra ${ }^{4}$.

Uma das grandes lacunas do conhecimento da cidade de Aeminium durante o período romano é, precisamente, a natureza da ocupação do espaço onde hoje se encontra o Pátio da Escolas.

A existência de vestígios que comprovam a ocupação romana neste espaço advém da existência de um conjunto de espólio (lítico, metálico, vítreo e, fundamentalmente, cerâmico) recolhido por Nogueira Gonçalves aquando da abertura da vala para implantação da estátua de D. João III (Setembro de 1949) e posteriormente publicados por Bairrão Oleiro (OleIRO 1952). No entanto, a impossibilidade na altura de proceder a escavações arqueológicas, levou à parcial interpretação dos mesmos. Ficou-nos felizmente o registo do seu achamento em associação com dois muros paralelos de alvenaria, a aproximadamente dois metros de profundidade (OLEIRO 1952 69).

Como já foi referido, a primeira intervenção arqueológica realizada neste espaço ocorreu no Verão de 2000. Esta acção tem como finalidade última a revalorização do conjunto monumental do Paço das Escolas. As sondagens arqueológicas que então se implantaram visavam comprovar os dados fornecidos pelos resultados da campanha de prospecção geofísica previamente realizada, bem como comprovar o perímetro da muralha da primitiva Alcáçova. Os vestígios de época romana postos a descoberto logo na fase inicial dos trabalhos, alargaram a amplitude cronológica a analisar, sendo inclusive um dos principais objectivos para o alargamento da área escavada nos anos sequentes.

4 Não poderemos deixar de expressar um profundo agradecimento à Professora Helena Catarino, uma vez que permitiu a apresentação dos resultados das escavações no Pátio da Universidade e no Colégio da Trindade, onde tem a co-direcção técnico-científica dos trabalhos. 
Foram desde então realizadas mais duas campanhas (2001 e 2002), encontrando-nos nesta fase a programar uma nova intervenção, que decorrerá em 2007.

Desta forma, implantaram-se quatro sondagens no Pátio da Universidade: uma no centro, junto à base da estátua de D. João III (Sondagem 1) (Foto 2); um locus de sondagem foi aberto junto do cubelo/gigante, entre a Capela Manuelina e a Biblioteca Joanina (Sondagem 2); no prolongamento para poente da sondagem 1 foi implantada a Sondagem 3 e, por fim, no prolongamento directo para Norte da área de sondagem 3 foi determinada a Sondagem 4 (Foto 1). Para além destas áreas de intervenção na zona central do Pátio, foram efectuadas diversas picagens de paredes no interior do edifício do Paço, no interior da Faculdade de Direito e na Reitoria, que visaram o reconhecimento do perímetro da muralha da Alcáçova, sua técnica construtiva e cronologia. Da mesma forma foi ainda desentulhado parcialmente um espaço, depois identificado como uma torre, hoje no interior da Faculdade de Direito, oposta a uma outra situada na actual sala dos Archeiros, que defenderiam a porta de acesso ao recinto. A estratégia de escavação adoptada seguiu a metodologia preconizada por Harris, na obra Principles of Archaeological Stratigraphy, por escavação em open area, com individualização de cada realidade arqueológica (Unidade Estratigráfica - U.E.), descritas individualmente em Fichas de Unidade Estratigráfica, e depois conjugadas através da Matriz de Harris. Ao contrário do desejado, a picagem de paredes não obedeceu propriamente aos métodos preconizados pela arqueologia da arquitectura, aplicada à leitura estratigráfica de construções com cota positiva. A exiguidade das intervenções e a distância entre cada uma apenas permitiu obter leituras pontuais que, no entanto, se revelaram pertinentes e indispensáveis para a obtenção de um melhor conhecimento sobre o possível perímetro da primitiva alcáçova, sua técnica construtiva e dispositivos de defesa.

Ao longo dos séculos, o actual Pátio da Universidade sofreu múltiplas alterações espacio-funcionais, com diversas intervenções e destruições que foram alterando por completo a primitiva fisionomia desta plataforma da acrópole da cidade (CATARINO e FILIPE, 2003a: 2).

Uma vez que a ocupação medieval islâmica deste espaço tem tido um esforço de publicação superior à do período romano, optámos neste apontamento por privilegiar uma maior descrição das estruturas deste 
primeiro momento de ocupação do actual Pátio das Escolas, em detrimento do segundo, mais conhecido.

$\mathrm{Da}$ área até agora intervencionada destaca-se o reconhecimento de uma domus que constitui, até ao momento, o conjunto edificado mais coerente de época romana detectado no Pátio. É também um dos poucos exemplos de arquitectura doméstica da cidade de Aeminium.

$\mathrm{O}$ estudo e a interpretação deste espaço residencial de época romana encontram-se dificultados pela construção, em época medieval, de uma rua que corta a leitura dos diferentes espaços reconhecidos: de um lado e do outro da rua ficou perceptível uma parte das termas, um átrio/cozinha, uma sala incompleta pavimentada a mosaicos, uma cisterna e parte da estrutura de um lagar de azeite ou vinho. Uma tentativa de atribuição das funcionalidades dos diferentes espaços identificados, bem como da distribuição interna dos compartimentos reconhecidos foi já sumariamente elaborada (CATARINO e FILIPE 2003).

Muito provavelmente a porta de acesso desta casa localizar-se-ia a sul, entrando-se por um corredor de aproximadamente dois metros de largura. Este separaria a zona da sala do mosaico (a nascente) da cisterna (a poente) e abriria para um amplo espaço aberto que serviria de área central de distribuição - a sul a sala do mosaico, a sudoeste a cisterna; para leste as termas privadas e a oeste o lagar.

A sala pavimentada a mosaico deverá ter funcionado como triclinium, pelas dimensões e qualidade colocada no revestimento do nível de solo e ao revestimento parietal, de que ainda sobrevive um fragmento na parede nascente (Foto 3).

Esta sala deverá corresponder a um espaço com $5,5 \mathrm{~m}$ de comprimento, a julgar pelo que ainda se encontra conservado; quanto à determinação da sua largura, encontra-se bastante dificultada, pelo corte que a rua medieval efectuou na parede e no mosaico. Ainda conserva $3,8 \mathrm{~m}$ de largura, devendo, por isso, ultrapassá-los.

Embora bastante incompleto, do mosaico que pavimentava o chão desta casa recuperou duas áreas onde se conservou mais intacto. Assentando directamente sobre um piso de opus caementicium, reconhecem-se ainda os motivos laterais desta composição: friso com SS preenchidos; duplos nós de Salomão; triângulos preenchidos a negro (Foto 4); frisos com "torres" a azul e ângulos preenchidos a amarelo e/ou branco. Estes motivos foram realizados recorrendo a pequenas tesselas polícromas (brancas, negras, amarelas, azuis e vermelhas), de calcário. O estado de destruição do mosaico não nos permite reconhecer o seu motivo cen- 
tral $^{5}$. Teremos de conjugar o estudo estilístico deste pavimento com as informações estratigráficas advindas dos estratos prévios à sua construção, os da remodelação deste pavimento e sua posterior destruição, para podermos precisar, com maior segurança, a sua cronologia.

Não é de descartar a hipótese de este espaço ser o próprio atrium de entrada nesta domus. Neste caso, a porta de entrada estaria actualmente sob a base da estátua de D. João III. Se conjugarmos esta hipótese com facto de Bairrão Oleiro nos descrever um conjunto de espólio de época romana, depositado entre dois muros paralelos de alvenaria, a aproximadamente dois metros de profundidade, encontrado quando da abertura da vala para a colocação da referida estátua, poderá ganhar nova coerência esta hipótese. Nesta altura foram recuperados quatro fragmentos de pinturas parietais, policromos, sem motivo definido; um tijolo de coluna que possui, na face curva, a palavra PRIMI, alguns pesos de tear e, fundamentalmente, um conjunto de lucernas e de fragmentos de terra sigillata atribuídas aos séculos I/II d.C. (OleIRo 1952 70-82). Ora, tanto a profundidade a que foram detectados os vestígios como a natureza dos mesmos é coincidente com aquelas por nós registada.

Acresce ainda o facto de, em 2001, se ter recolhido do interior da cisterna dezenas de tijolos de quadrante, de entre os quais um tijolo com a mesma marca $P_{R I M I}$, o que indiciará a presença de um espaço colunado sobre a área da cisterna ou nas suas proximidades.

A sala do mosaico sofreu alterações durante a Antiguidade tardia, num período balizado entre os séculos V e VII. Ao pavimento tesselar sobrepõe-se uma fina camada negra, com $2 \mathrm{~cm}$ de espessura, imediatamente seguida por um piso de argila, obstruindo por completo o mosaico. Possuem as mesmas características das verificadas na remodelação do átrio/cozinha, pelo que estas alterações terão sido sincrónicas. Estão associados a cerâmicas romanas tardias. Na transição da Antiguidade tardia para a Alta Idade Média ter-se-á destruído uma parte do

5 A destruição intencional de motivos mitológicos na Antiguidade tardia por novos proprietários, agora cristãos, é um factor a considerar, tanto mais que se verificaram noutros pontos do mundo romano (López MonTEAGUdo 1990 353-365).

6 Será de todo pertinente confrontar os dados inscritos nos tijolos com a epigrafia local e procurar paralelos para estes tijolos, determinando assim se estes são fruto de fabrico local ou regional. Segundo informação oral, todavia ainda não confirmada, em Conimbriga encontramos tijolos com a mesma marca.

Conimbriga, 45 (2006) 337-357 
mosaico, com a abertura de uma fossa detrítica que cortou parte da parede leste da sala.

Ainda nesta época são construídas algumas paredes que assentam directamente nas camadas argilosas que se sobrepuseram ao mosaico.

A estas estruturas sobrepõem-se depois outras, de casas medievais, associadas nomeadamente a materiais de época islâmica e da Reconquista (cerâmica vermelha pintada a branco e panelas de cozedura redutora com incisões profundas nas asas).

A cisterna que abasteceria as necessidades de água desta casa foi identificada e escavada na campanha de 2001. Esta estrutura surge no prolongamento, para poente, da sala pavimentada a mosaicos anteriormente descrita (Foto 7).

A sua estrutura tem planta rectangular, com parede rectilínea no lado leste e em arco de círculo no lado poente. Interiormente está totalmente revestida a opus signinum, tendo o piso rebordo de meia cana, na ligação com as paredes, e um orifício/ralo para escoamento de águas, localizado junto da parede sul. No topo da parede leste verifica-se uma abertura, com $60 \mathrm{~cm}$ x $35 \mathrm{~cm}$, relacionada com canais de gestão e condução de água. Tem planta (quase) rectangular, com 6,05 m de comprimento e 1,72 $\mathrm{m}$ de largura. $\mathrm{O}$ arranque da abóbada surge aos $2 \mathrm{~m}$ de altura, alcançando, no ponto mais alto, 2,5 m. Ao analisar a cobertura da abóbada cremos ter existido uma remodelação nesta estrutura, em momento de difícil precisão cronológica. A abóbada apresenta ainda evidências de duas violações/destruições que afectaram também o piso que a cobria.

Sobre a cisterna existiria uma divisão, cujo piso era de opus signinum de boa qualidade. Este piso encontra-se à mesma cota, para poente, do piso do mosaico. Deve ter correspondido a um pequeno tanque ou impluvium colocado sobre o piso deste sector da domus.

Através da análise do espólio cerâmico encontrado nos sucessivos níveis de entulho depositados no interior deste espaço, podemos concluir que a cisterna terá sido entulhada, num primeiro momento, num período indeterminado da Antiguidade tardia, quando se destroem/alteram áreas habitacionais da casa, uma vez que se encontram restos de estuques e tesselas misturadas com cerâmicas predominantemente romana e tardo-antiga. Destacam-se pequenas bilhas de cerâmica laranja fina com pintura a branco e vináceo, cerâmica de pasta branca de tipo casca de ovo, formas abertas e fechadas de fabrico manual/torneta de pastas grosseiras e desengordurantes de grãos médios, um fundo de ân- 
fora Almagro 51c, imitações de sigillata em cerâmica comum, da forma Drag.27, ou seja, tigelas com paredes de dupla curvatura e fundo de pé anelar, de cozedura redutora e arrefecimento oxidante e superfícies que oscilam entre o tom laranja e o ocre-acinzentado. Do interior da cisterna foram ainda recolhidos dezenas de tijolos de quadrante. Depois deste primeiro momento de abandono, verificam-se ainda mais duas fases: uma com materiais atribuídos ao período altomedieval e outra, mais superficial, com materiais cerâmicos atribuíveis à Baixa Idade Média/ /inícios da Época Moderna, estando esta unidade relacionada com o abatimento das zonas central e lateral da abóbada.

Esta domus possuía ainda um pequeno complexo termal, distribuído por três salas: o caldarium, onde o hipocausto, a norte, se encontra directamente relacionado com canalizações de condução de água para este espaço; possíveis salas de tepidarium e frigidarium (eventualmente com piscina?), respectivamente ao centro e no extremo sul. Estas estruturas encontram-se muito destruídas, não sendo possível aferir com grande precisão quer as suas dimensões, quer a sua cronologia original. Os materiais arqueológicos encontrados sobre o solo são escassos e pouco elucidativos sobre a cronologia de abandono, eventualmente a partir dos séculos IV/V.

A poente do espaço de átrio/cozinha e, para norte da cisterna, identificou-se uma área que corresponderá a um lagar de época romana de produção de azeite ou de vinho (Foto 5). Sobre um piso de argila (sucessivamente remodelado) encontrou-se uma mó olearia, em pedra arenítica (Foto 6).

Esta estrutura deve ter sido abandonada no mesmo momento do abandono da cisterna e da cozinha, uma vez que se identificaram cerâmicas atribuídas a horizontes cronológico-culturais atribuíveis à Antiguidade tardia.

Ocupando um espaço central, parece ter existido um espaço que, em momentos distintos, desempenhou funções diferentes: de átrio e de cozinha.

Aqui se instala uma cozinha, ainda em época romana, associada a uma camada de abandono que inclui cerâmica tardo-romana, sobretudo peças de usos culinário, e a um solo de habitat, feito de argila bem compactada. Posteriormente, constrói-se uma parede sobre esta lareira, anulando-a e instala-se outra, no centro agora estabelecido por esta nova parede. Ao contrário da primeira estrutura de combustão, a nova não apresenta vestígios de fogo no lar. Esta "lareira" (à falta de melhor 
designação) é de planta rectangular, com 1,20 x 2 m, e apresenta a seguinte técnica construtiva: ladrilhos colocados na vertical, lateralmente reforçados por um friso exterior de pedras grosseiramente aparelhadas. O lar é construído com ladrilhos e tégulas invertidas, bem argamassadas entre si. Convém notar que esta estrutura é semelhante a uma outra identificada em Centum Cellas, aparecendo também um registo fotográfico de uma estrutura em tudo semelhante nas Fouilles de Conimbriga (Alarcão e ETIENNE 1977 Planche LXXIV, fot. 4), esta última atribuída a uma ocupação Cláudia, o que nos parece uma cronologia muito recuada, se comparada com o contexto estratigráfico em que a "lareira" do Pátio foi identificada. A análise sumária do espólio cerâmico em conexão com o abandono da primitiva lareira sugere um momento tardo-romano para esta ocorrência, pelo que, a construção da nova estrutura deve ter ocorrido entre este momento e o início da Antiguidade tardia.

Esta casa respeitaria uma orientação aproximadamente segundo os pontos cardeais, podendo equacionar-se o facto de respeitar alinhamentos de cardines e decumani secundários, alinhados a partir da orientação do critopórtico e do fórum da cidade, comprovando assim uma tentativa de gestão do espaço segundo um modelo ortogonal, em época romana. A localização do lagar, no extremo norte da casa, corresponde a uma solução vulgar no mundo romano, encontrando-se inúmeros paralelos para esta disposição no quarteirão nordeste de Volubilis (ETIENNE 1960). Estes espaços eram frequentemente localizados de forma a possuírem uma loja aberta para a rua, para assim se efectuar a actividade comercial de forma directa e independente.

Conjugando os escassos dados fornecidos pelo espólio encontrado junto aos níveis de habitat deste espaço, a reduzida dimensão das termas, com a possibilidade de reconstituição da funcionalidade dos espaços apresentada, podemos tentar balizar a construção desta casa na segunda metade do século I d.C.

De facto, uma análise mais detalhada da planta da domus que ocupava parte do espaço do actual Pátio da Universidade, indicia um tipo de planta muito simples, apontando para uma casa de átrio, de tipo pompeiano, "forma mais antiga da residência senhorial urbana romana" (AlARCÃo 1985 7). Encontramos paralelos para esta domus na descrição da casa del chirurgo, na obra de Jorge de Alarcão sobre o estudo da casa romana, nomeadamente ao afirmar a existência de um tanque pouco profundo para recolha das águas da chuva - impluvium -, sob o 
qual havia uma cisterna (ALARCÃo 1985 7), situação idêntica à verificada no Pátio ${ }^{7}$.

Esta casa conheceu importantes remodelações durante a Antiguidade tardia, conforme já demonstrado, o que comprova a vitalidade deste espaço e a continuidade de ocupação pela mesma, ou por outra família de proprietários. Só na Idade Média, a memória deste espaço como núcleo de habitação unifamiliar será quebrada, mas novas funções são agora exigidas a este espaço sobranceiro ao Mondego: albergar um novo poder recém-chegado à cidade. Impunha-se a construção do Alcácer e da Alcáçova da cidade islâmica, edifício que perdurou até aos nossos dias, coberto por sucessivas capas de poder (régio primeiro, universitário depois). De então até ao presente várias foram as intrusões que este complexo conheceu: primeiro como inevitável fonte de matériaprima (leia-se pedra) para a construção do recinto fortificado e, posteriormente, para a construção dos edifícios emblemáticos da Universidade Coimbrã ${ }^{8}$.

Mas a intervenção arqueológica realizada no Pátio da Universidade de Coimbra fica ligada à história pela comprovação arqueológica da presença de testemunhos inequívocos e irrefutáveis da estrutura palatina de governação da cidade de Coimbra durante o período islâmico: o Alcácer.

De facto, como recentemente foi afirmado "a época islâmica [em Coimbra] não se materializa apenas na presença de materiais arqueológicos em associação com pisos e lixeiras, mas sobretudo pelas muralhas da alcáçova/alcácer, que tem planta quadrangular, com 74/78 m por 80/81 m de lado, numa área aproximada de $6000 \mathrm{~m}^{2}$ (Foto 8). Edificado no período omíada, seguindo modelos orientais e peninsulares (CATARINO 2005 205-206), a sua técnica construtiva é semelhante à de outros tramos da muralha da medina, o que pode corresponder a um programa mais vasto de reforço defensivo da cidade" (CATARINO e FILIPE 2005).

7 Pensamos todavia que esta casa não terá a mesma cronologia do que a pompeiana, sendo a de Coimbra certamente posterior ao século IV a.C.

8 Ao realizar a Sondagem 2, junto do cubelo/gigante que separa a Capela Manuelina da Biblioteca Joanina, identificou-se na parede da Capela um silhar de época romana, ainda com um fragmento de estuque incorporado. Este não deve ser caso único, nem sequer a excepção à regra. 
Na área escavada até ao momento no Pátio obtiveram-se resultados que permitem reconhecer vestígios da ocupação humana em épocas romana, tardo-antiga, medieval, moderna e contemporânea. Nesta testemunham-se ainda diferentes funções atribuídas a este espaço: em época romana é uma área residencial; no período islâmico é nele implantado o Alcácer da cidade; depois da conquista cristã, é aqui instalado o Paço Real, que depois se transforma em sede da Universidade portuguesa.

b) Instalado no século XVI nas costas do Paço Real, ergue-se o Colégio Universitário da Ordem da Santíssima Trindade (Foto 9).

Será quando a Universidade portuguesa assume um carácter verdadeiramente renascentista, que é construído o Colégio da Santíssima Trindade, na alta coimbrã, em 1562. No entanto, já em 1552, alguns frades estudantes daquela Ordem religiosa frequentavam os Estudos Gerais, vivendo colegialmente numa casa junto à Sé.

As obras de construção do edifício colegial tiveram início no ano de 1562, no terreno entre a Couraça de Lisboa e a rua que mais tarde se veio a denominar Rua da Trindade, junto ao Paço Real. Encontra-se numa zona privilegiada, moldada pela muralha medieval, abaixo do Arco da Traição, onde começa a descer a colina.

O Colégio da Trindade não é uma construção de raiz: as construções pré-existentes, compradas pelos Trinos, foram aproveitadas para a nova construção, sendo modificadas, acrescentadas e trabalhadas à medida das suas necessidades, tornando-se úteis à vida colegial. $\mathrm{O}$ destino deste colégio, em 1834, foi idêntico a muitos outros: com a extinção das Ordens religiosas, o colégio foi fechado e os seus bens inventariados. A 14 de Maio de 1849, parte do edifício foi vendido em hasta pública e, a 12 de Junho de 1895, e depois de ter servido para vários fins, também a igreja foi adquirida pelo então proprietário do resto do edifício.

Os trabalhos arqueológicos aqui realizados 9 inserem-se no projecto de requalificação e transformação deste espaço em Centro de Estudos Europeus. As sondagens localizam-se nas zonas onde se previa a instalação enterrada de equipamentos relacionados com o funcionamento das futuras instalações do Centro de Estudos Europeus. Era então urgente avaliar previamente as potencialidades arqueológicas destas áreas.

9 Estes trabalhos têm co-direcção técnico-científica de Helena Catarino e Sónia Filipe. Contam ainda, desde 2004 com a colaboração permanente de Vera Santos. 
Dos trabalhos arqueológicos já realizados (principalmente duas grandes campanhas de escavação, em 2004 e 2005), tanto no interior do espaço colegial como no pátio do mesmo, foi possível, tal como no Pátio das Escolas, verificar uma diacronia de ocupação compreendida entre o período romano e a actualidade.

Da complexidade de estruturas identificadas podemos evidenciar: a identificação de um compartimento parcialmente escavado na rocha, de época romana, mais concretamente do período alto-imperial, cujas paredes apresentam pintura mural. Este compartimento, associado a um piso em opus signinum, possui um alinhamento claramente distinto do actual, aproximando-se de alguns alinhamentos de muros identificados no Pátio. Possui três paredes em associação, das quais uma se encontra completa, medindo aproximadamente $3,5 \mathrm{~m}$ de comprimento. As outras duas paredes foram cortadas pela construção do colégio, pelo que as dimensões exactas deste espaço, bem como a sua função são, até ao momento, desconhecidos. Nos compartimentos confinantes escavados não foram identificados mais vestígios desta natureza que permitam esclarecer as dimensões e tipologia do espaço habitacional onde estaria incorporado. Este é o testemunho de época romana mais significativo até agora identificado no Colégio da Trindade.

Do período medieval islâmico identificam-se algumas evidências, quer estruturais, quer, e fundamentalmente, ceramológicas, que apontam para a ocupação deste espaço neste período.

Ainda dentro do período medieval, foi identificada uma fase de ocupação que corresponderá à ocupação residencial prévia à instalação do Colégio, ocupação essa muitas vezes alterada, ao nível estrutural, logo nos inícios da ocupação colegial.

Ligada à vida quotidiana deste espaço de ensino surgem-nos inúmeros testemunhos que comprovam uma gestão empenhada e permanente dos espaços por que eram responsáveis neste pedaço da colina coimbrã (Foto 10).

Por fim, aparece o testemunho de toda essa sucessiva adulteração/alteração que todos estes espaços conheceram ao longo dos séculos XIX e XX.

No exterior do edifício colegial, no pátio interior fechado à rua da Couraça de Lisboa por um imponente muro, foram recentemente identificadas interessantes estruturas ligadas à captação, reserva e gestão das águas, nomeadamente um poço-cisterna com 4,5 m de profundidade, e uma grande estrutura circular, que aparenta ter sensivel- 
mente $7 \mathrm{~m}$ de diâmetro interno (Foto 11). Foram ainda identificados e exumados um conjunto de enterramentos de jovens adultos do sexo masculino (Foto 12).

Aguardamos com expectativa a progressão dos trabalhos arqueológicos nesta área.

c) O local onde se implanta o Laboratório Chimico constitui, no perímetro da Alta universitária, uma dos pouco sítios que escapou à fúria demolidora ocorrida no Estado Novo. Daí que o seu potencial arqueológico seja elevado. Acresce a sua localização, junto ao perímetro da cerca coimbrã, da qual, nas imediações do espaço laboratorial, surgem dois eloquentes testemunhos: duas pequenas construções que correspondem a uma torre defensiva e a um ângulo da muralha, que já surgem representadas em gravuras do século XVIII (AAVV 2004).

Desta forma, a perspectiva de remodelação deste espaço para instalação da primeira fase do Museu da Ciência, veio implicar a programação de uma actividade arqueológica que visasse minimizar possíveis impactes negativos, no subsolo e no próprio edifício, ocorridos no decurso da execução do projecto. A pequena equipa de arqueologia envolvida procurou, desde primeira hora, trabalhar em estreita colaboração com a equipa projectista, com a museologia e demais envolvidos no processo, de forma a efectuar um programa de trabalhos arqueológicos que respondesse às necessidades das alterações projectadas para o local. Realizaram-se desta forma escavações arqueológicas, localizadas no exterior do edifício, onde estavam previstas grandes afectações do subsolo, acompanhamento arqueológico de pequenas perturbações da cota actual no interior do edifício e trabalhos arqueológicos a cota positiva, materializada essencialmente pela picagem de paredes e seu posterior estudo.

Como resultados preliminares das áreas escavadas, podemos apontar a presença de várias estruturas hidráulicas, com cronologias compreendidas entre a medievalidade e a época de Pombal, "que vêm atestar a importância que a gestão da água assumiu para as comunidades humanas no passado" também neste espaço (FILIPE e MoRGADo 2004 21). Terá sido a construção da mina de água que drena as águas da cisterna do Laboratório, conduzindo-as até ao vale da Ribela, que constituiu o maior factor de alteração das naturais condições de estratificação arqueológica.

Nesta sondagem pudémos ainda verificar testemunhos da laboração inicial do Laboratório Chimico, nos finais do século XVIII e inícios 
do XIX, essencialmente materializados pela presença de cerâmicas e vidros ligados a esta actividade.

Numa segunda área de sondagem, localizada junto à encosta voltada à rua Padre António Viera, foi identificada uma estrutura subterrânea de grandes dimensões, que terá funcionado, a um dado momento, como uma reserva estratégica de água (Foto 15). Esta estrutura está colmatada de entulhos quase até ao seu topo, ao longo de, pelo menos, $18 \mathrm{~m}$ de comprimento, com uma largura aproximada entre 3,90 m e 4,20 m. Desconhece-se a sua profundidade, uma vez que apenas foi parcialmente escavada em profundidade numa pequena área (a do abatimento da abóbada), tendo a progressão sido interrompida aos 6,5 m por questões de segurança, sem que se tenha alcançado a base. A função original deste grande espaço subterrâneo terá de aguardar a continuação dos trabalhos nesta área, com a escavação integral do espaço identificado. Existem fortes probabilidades de ter uma função original associada à estrutura defensiva medieval de Coimbra (Foto 16).

Uma vez no interior do edifício laboratorial, efectuámos picagens em estruturas parietais que se revelavam "suspeitas" de esconder, em si mesmas, camadas da história da ocupação deste espaço, de forma a podermos libertar o espaço de algumas paredes recentes que alteravam a leitura das áreas iniciais do laboratório.

De facto, não só conseguimos identificar estruturas, ou vestígios delas, associadas ao primeiro edifício construído propositadamente para servir de laboratório de física experimental na Europa, como também, e mais importante ainda, a manutenção de estruturas do antigo refeitório do Colégio de Jesus, que se implantava nesta zona desde o século XVI.

No primeiro caso, identificou-se parte de um antigo forno do século XVIII, bem como os locais onde se localizavam as baterias de fornos originais do laboratório, responsáveis pelo fornecimento de energia para a realização dos experimentos cientificos e, simultaneamente, fonte de calor. Estes trabalhos vieram complementar as riquíssimas informações cartográficas, da autoria de Guilherme Elsden, acerca do projecto original.

No segundo caso, somos obrigados a destacar a descoberta de um dos dois púlpitos que o Refeitório jesuítico possuía, em óptimo estado de conservação (Foto 13), e de vestígios do segundo, que lhe era simétrico. Se juntarmos a esta estrutura uma janela do século XVI (Foto 14) que se encontrava totalmente entaipada sob a parede do Laboratório, 
torna-se evidente e possível de comprovar arqueologicamente que o Laboratório Chimico da Universidade de Coimbra não é uma construção de raiz, uma vez que incorpora o corpo principal do refeitório jesuítico. Estes novos dados foram bem acolhidos pela equipa responsável pelo projecto, que efectuou as alterações necessárias à sua incorporação no futuro Museu da Ciência.

Em jeito de conclusão, podemos apontar o facto de diferentes e permanentes desafios serem colocados a quem intervenciona em espaços onde a pressão urbanística se sente há vários séculos. Nesta breve visita à Alta de Coimbra, podemos ver como em diferentes locais, mesmo que bastante próximos entre si, a realidade estratigráfica é radicalmente distinta.

De todos os espaços já intervencionados, bem como dos que se encontram em fase de programação, o Pátio das Escolas é o único que se destaca, uma vez que os objectivos da intervenção neste espaço emblemático da cidade, mas principalmente da Universidade, são, em primeiro lugar, de ordem científica. Todos os outros visam dar resposta a uma necessidade de intervir fisicamente em edifícios ou áreas do Pólo I universitário, pelo que a actividade desenvolvida procura actuar dando respostas a esta necessidade concreta.

A actividade que temos vindo a desenvolver procura actuar como ferramenta de gestão territorial neste espaço, ganhando redobrada importância na programação das actividades e acções a desempenhar no âmbito da preparação da candidatura a Património da Humanidade de parte dos espaços universitários. Não se trata pois, da procura de uma janela de tempo que permita um olhar contemplativo para o passado. Assume-se como uma tentativa diária de procurar coordenar as necessidades e acções do presente com a responsabilidade de sermos fiéis depositários de uma herança cultural riquíssima.

\section{BIBLIOGRAFIA:}

AAVV (2004), Laboratório do Mundo. Ideias e saberes da século XVIII. Pinacoteca. S. Paulo.

AlarCão, J. (1992), “A cidade romana em Portugal. Renovação urbana em Portugal na época Romana”, Cidades e História, Fundação Calouste Gulbenkian, Lisboa, pp. 73-128. 
AlarCão, J. (1985), Introdução ao Estudo da Casa Romana, Instituto de Arqueologia da Faculdade de Letras de Coimbra, Coimbra.

Alarcão, J. (1979), “As origens de Coimbra”, Actas das I Jornadas do GAAC, Coimbra, pp. 23-40.

Alarcão, J.; Etienne, R. (1977), Fouilles de Conimbriga, I - L'Architecture, Mission Archéologique Française au Portugal et Musée Monographique de Conimbriga, Paris.

CATARINO, Helena (2005), "Notas sobre o período islâmico na Marca Inferior (Tagr al Gharbí) e as escavações na Universidade de Coimbra", Muçulmanos e Cristãos entre o Tejo e o Douro (séc.s VIII a XIII), Câmara Municipal de Palmela/Faculdade de Letras da Universidade do Porto, pp. 195-214.

Catarino, Helena (2001), "Intervenção arqueológica no Pátio da Universidade de Coimbra: notícia dos resultados preliminares”, Informação Universitária, n. ${ }^{\circ} 11$ (Jan. a Mar.), Reitoria da Universidade de Coimbra, Coimbra, pp. 7-11.

CAtarino, Helena; Filipe, Sónia (2005), "Madinat Qulumbriya: arqueologia numa cidade da fronteira", no prelo.

Catarino, Helena; Filipe, Sónia (2003), “A História tal qual se faz no Pátio da Universidade de Coimbra: apresentação sumária dos vestígios de época romana”, $A$ História Tal qual se Faz, Edições Colibri / Faculdade de Letras da Universidade de Coimbra, Lisboa, pp. 49-63.

Catarino, Helena; FiLipe, Sónia (2003 a), “Arqueologia. Segredos e Lições do Pátio da Universidade”, Rua Larga. Separata O Paço das Escolas Revisitado, n. ${ }^{\circ}$ 1,Reitoria da Universidade de Coimbra, Coimbra, pp. 2-4.

Catarino, Helena; Filipe, Sónia (2001), "Segunda Campanha de Escavações no Pátio da Universidade de Coimbra: ponto da situação", Informação Universitária, n. ${ }^{\circ} 13$ (Jul. a Set.), Reitoria da Universidade de Coimbra, Coimbra, pp. 18-19.

Costa, Alexandre (1998), "A cidade e a Acrópole”, Monumentos, 8, Direcção Geral dos Edifícios e Monumentos Nacionais, Lisboa, pp. 100-103.

EtIEnNE, Robert (1960), Le quartier Nord-Est de Volubilis, 2 vol., Éditions E. de Boccard, Paris.

Figueiredo, A. C. Borges (1886), Coimbra Antiga e Moderna, edição Fac-similada (em 1996), Almedina, Coimbra.

FILIPE, Sónia; Morgado, Paulo (2004), "Intervenção no Laboratório Chimico: descobertas arqueológicas na Alta Universitária”, Rua Larga, 6, Reitoria da Universidade de Coimbra, Coimbra, pp. 21-22.

GIRÃo, A. Amorim (1943), "Civitas Aeminiensis (subsídios para um estudo geográfico da cidade de Coimbra)", Colectânea de estudos organizada pelo Instituto de Coimbra..., Coimbra, pp. 73-85.

Gonçalves, A. Nogueira (1947), Inventário Artístico de Portugal. Volume II - cidade de Coimbra. Academia Nacional de Belas Artes. Lisboa.

José, Frei Jerónimo de S. (1789), Historia Chronologica da Esclarecida Ordem da Santíssima Trindade, Livro III, Tomo I, Lisboa.

Lobo, Rui (1999), O Colégio da Trindade: estudo do edifício e levantamento da situação actual. Documento interno. 
LóPez Monteagudo, Guadalupe (1990), "Destruicción de mosaicos mitológicos por los cristianos", Antigüedad y Cristianismo, VII, Múrcia, pp. 353-365.

MANTAS, Vasco (1998), "O espaço urbano nas cidades do norte da Lusitânia”, Los Orígenes de la Ciudad en el Noroeste Hispânico (15-18 de Mayo de 1996), Lugo, pp. 355-391.

MANTAS, Vasco (1996), A rede viária romana da faixa atlântica entre Lisboa e Braga, I volume, Faculdade de Letras da Universidade de Coimbra, Coimbra, (Policopiado).

Mantas, Vasco (1992), "Notas sobre a estrutura urbana de Aeminium", Biblos, Vol. LXVIII, pp. 487-513.

Oleiro, J. M. Bairrão (1952), "Novos Elementos para a História de Aeminium. Os materiais romanos do Pátio da Universidade", Biblos, Vol. XXVIII, Coimbra, pp. 65$-82$.

Peacock, D. P. S.; Williams, D. F. (1986), Amphorae and the roman economy. An introduction guide, Longman, Londres e Nova Iorque. 


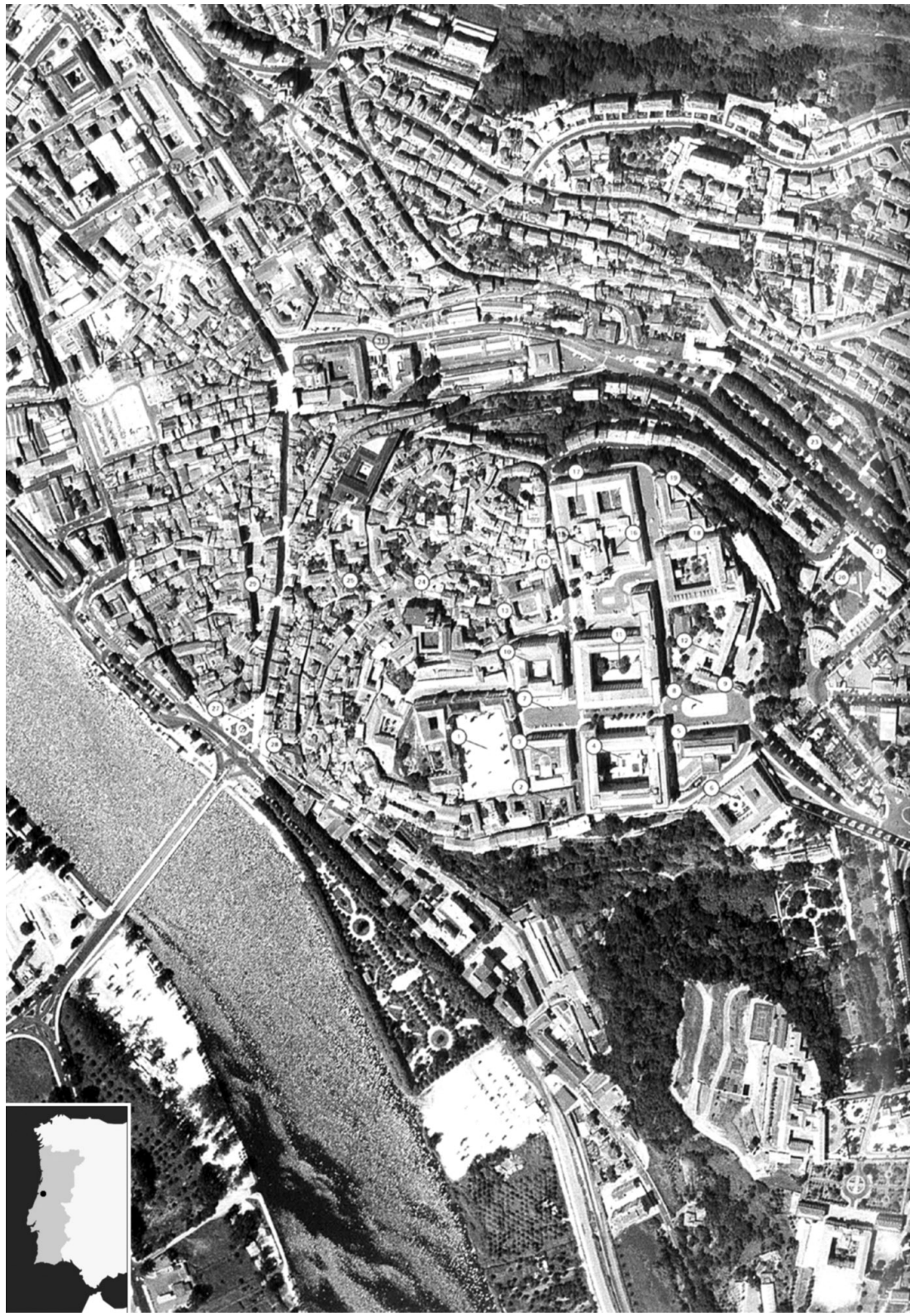

Fото 1 - Vista parcial da cidade de Coimbra

(Costa, 1998:100) 


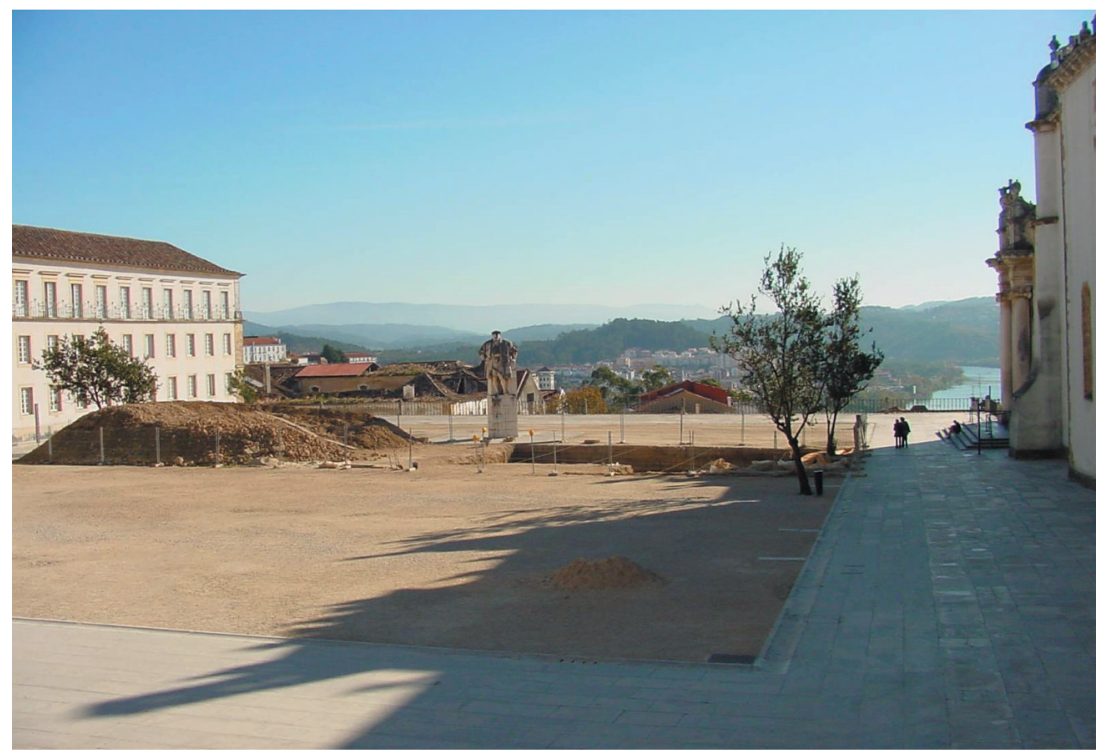

Foто 2 - Pátio da universidade com trabalhos arqueológicos em curso

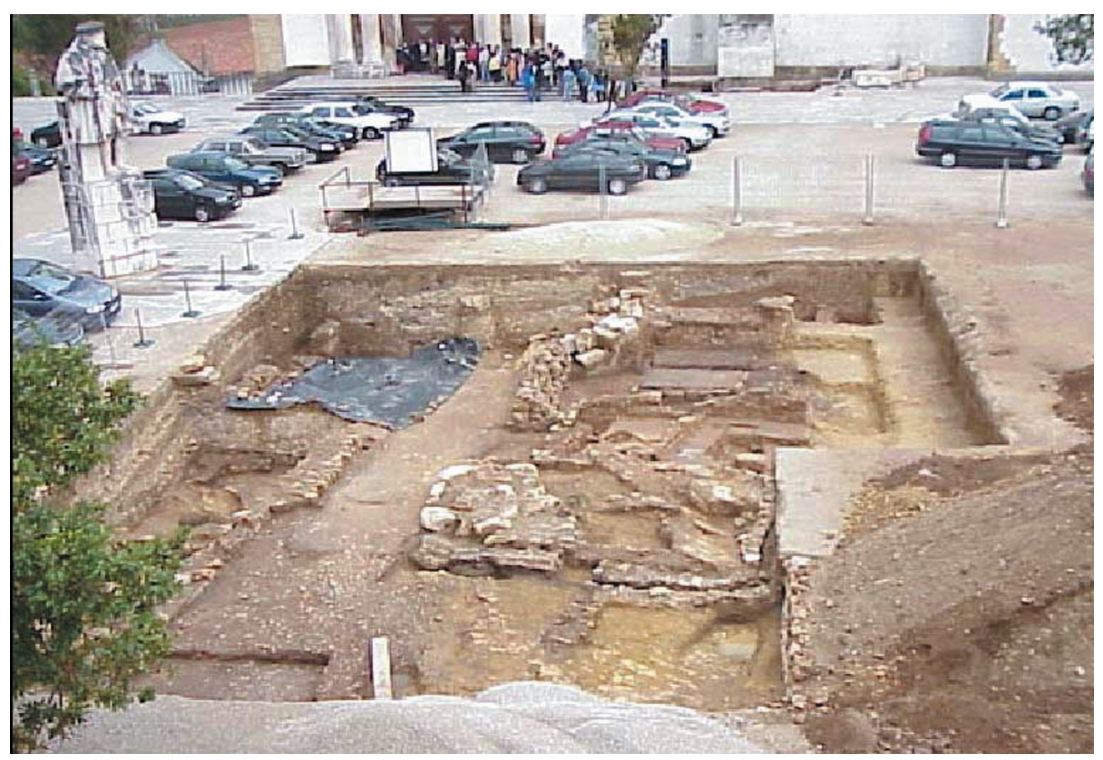

Fото 3 - Perspectiva geral dos trabalhos arqueológicos realizados em 2000 


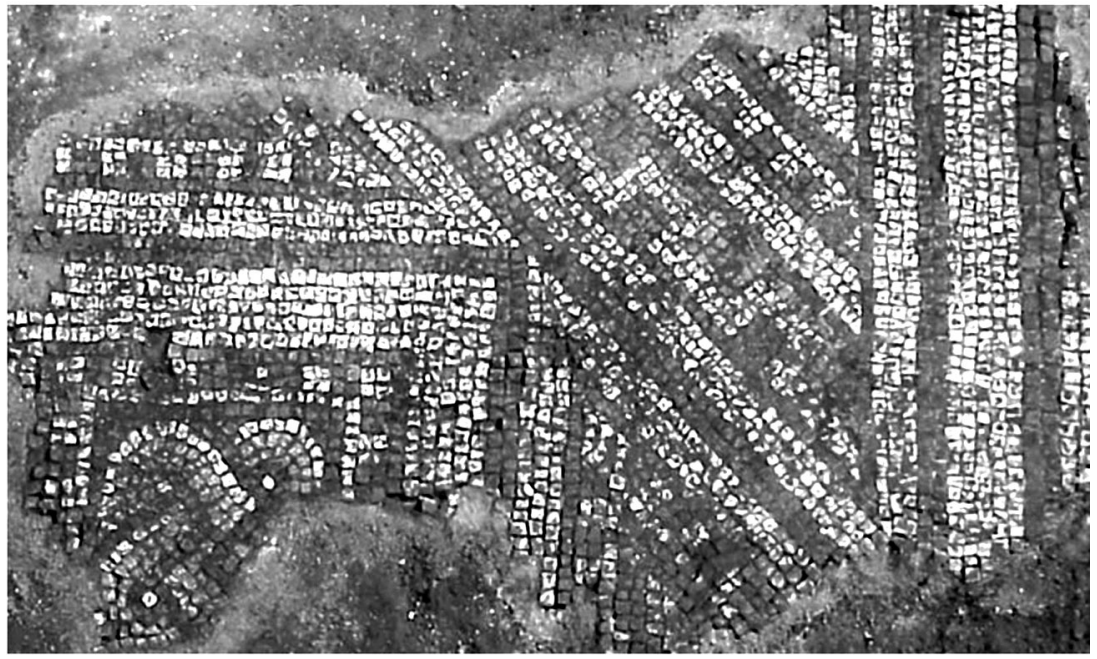

Fото 4 - Pormenor do fragmento de mosaico no Pátio das Escolas

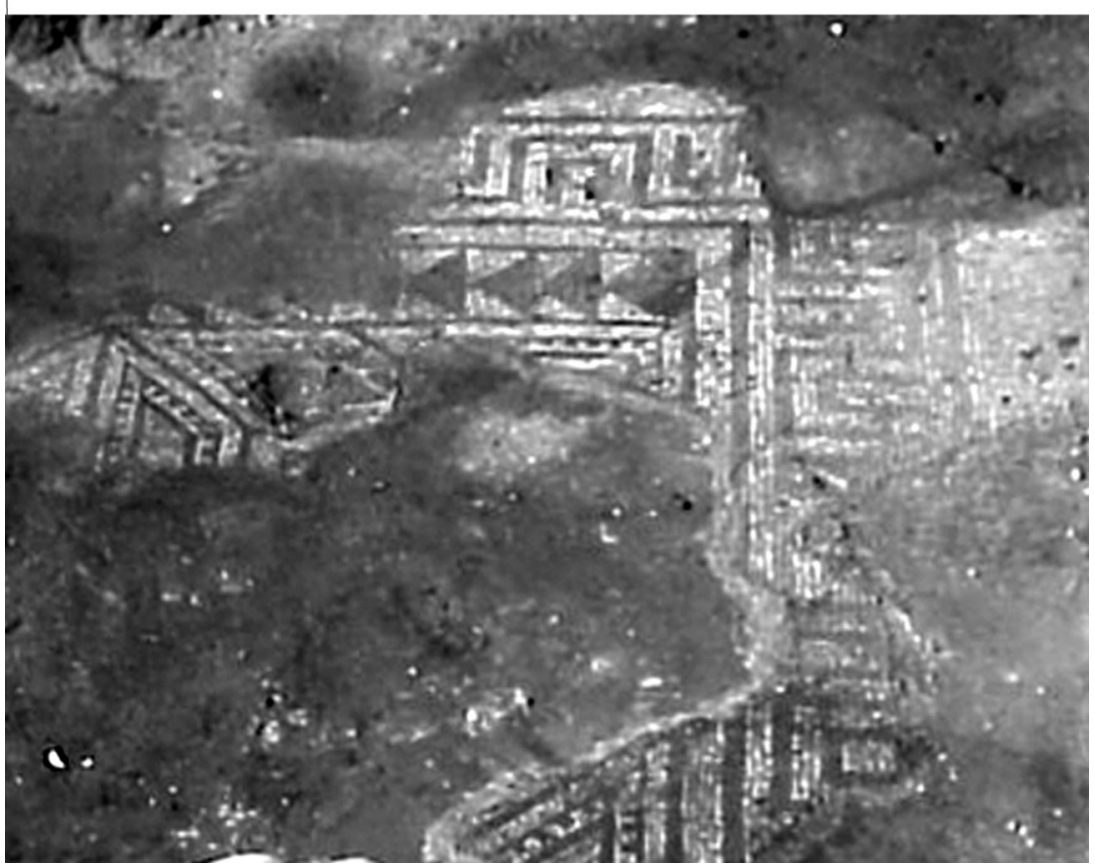

Fото 5 - Pormenor do triclinium, observando-se o pavimento de mosaico

e a sua parede este 


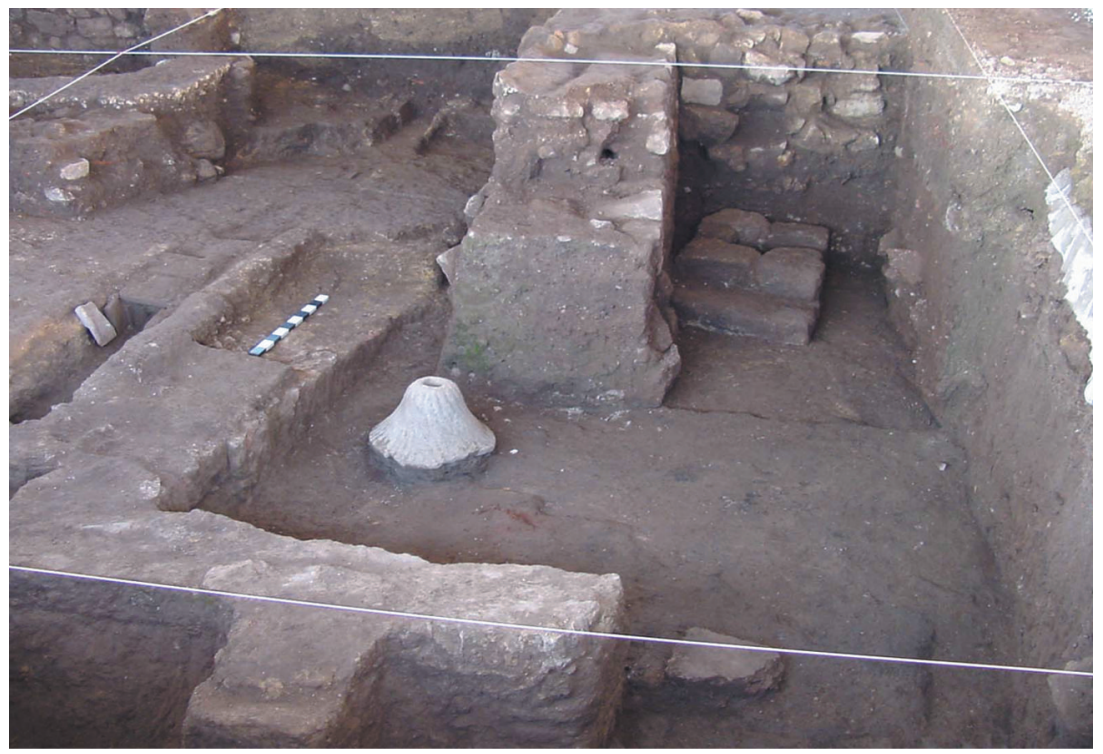

Fото 6 - Enquadramento da estrutura na sala do lagar

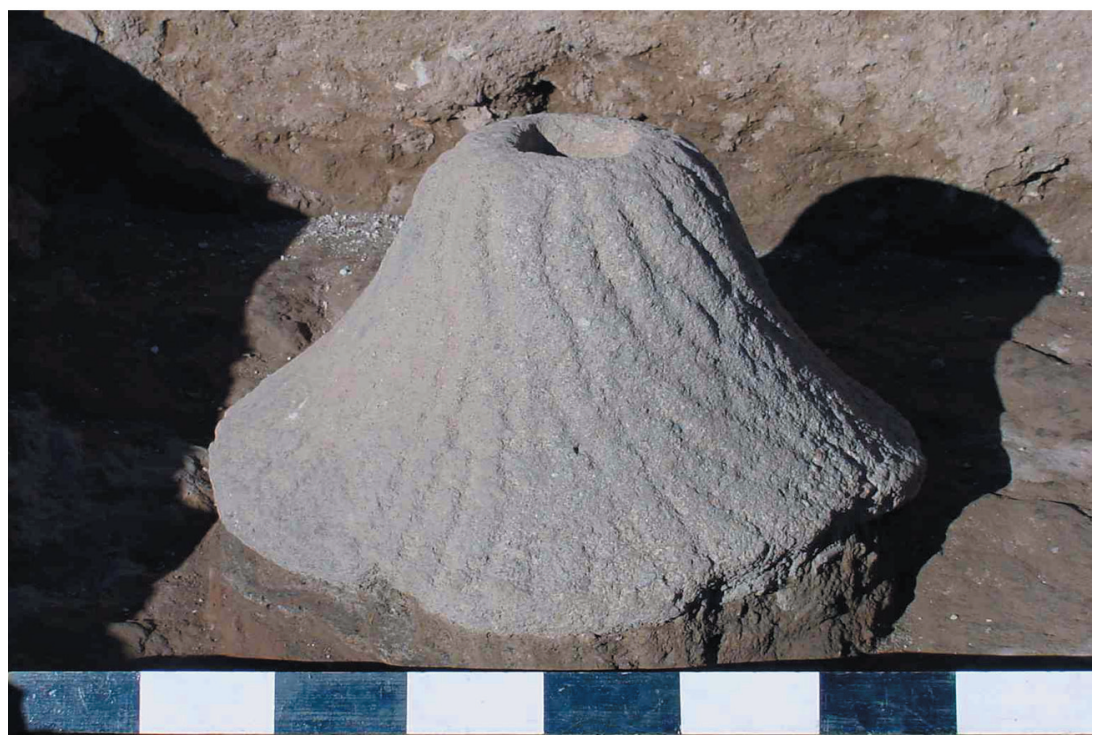

Fото 7 - Pormenor da mó olearia do lagar 


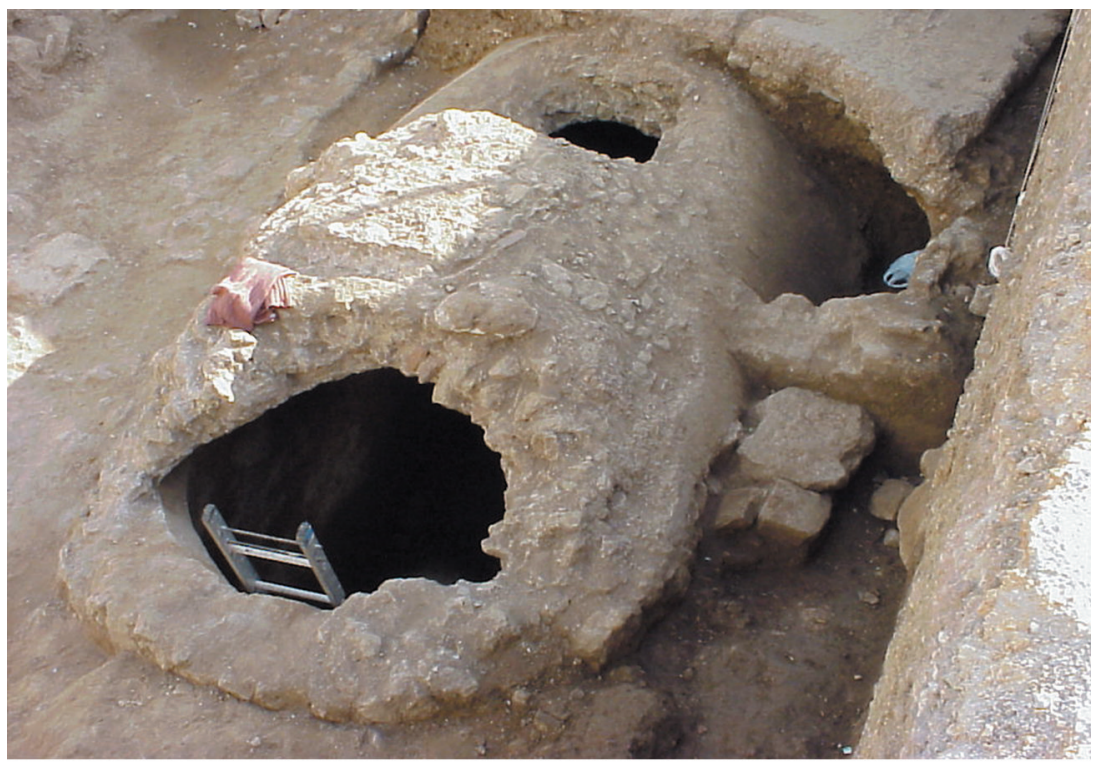

Fото 8 - Perspectiva da cisterna e da sala superior

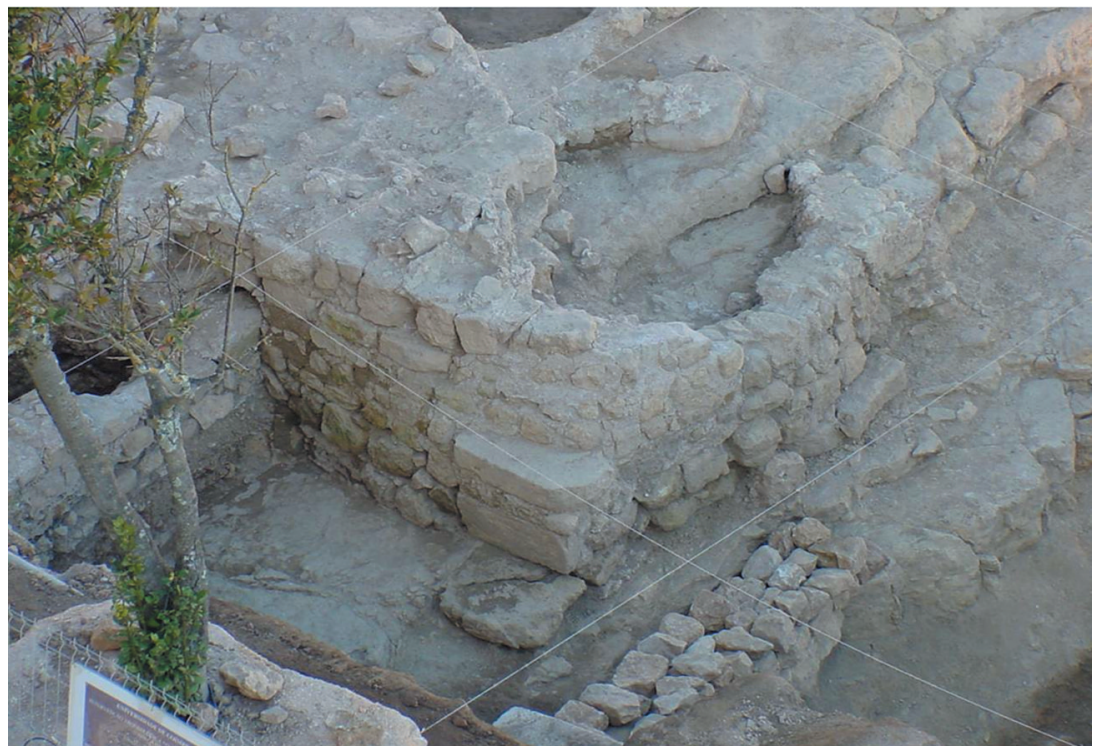

Fото 9 - Torre da muralha do período islâmico 


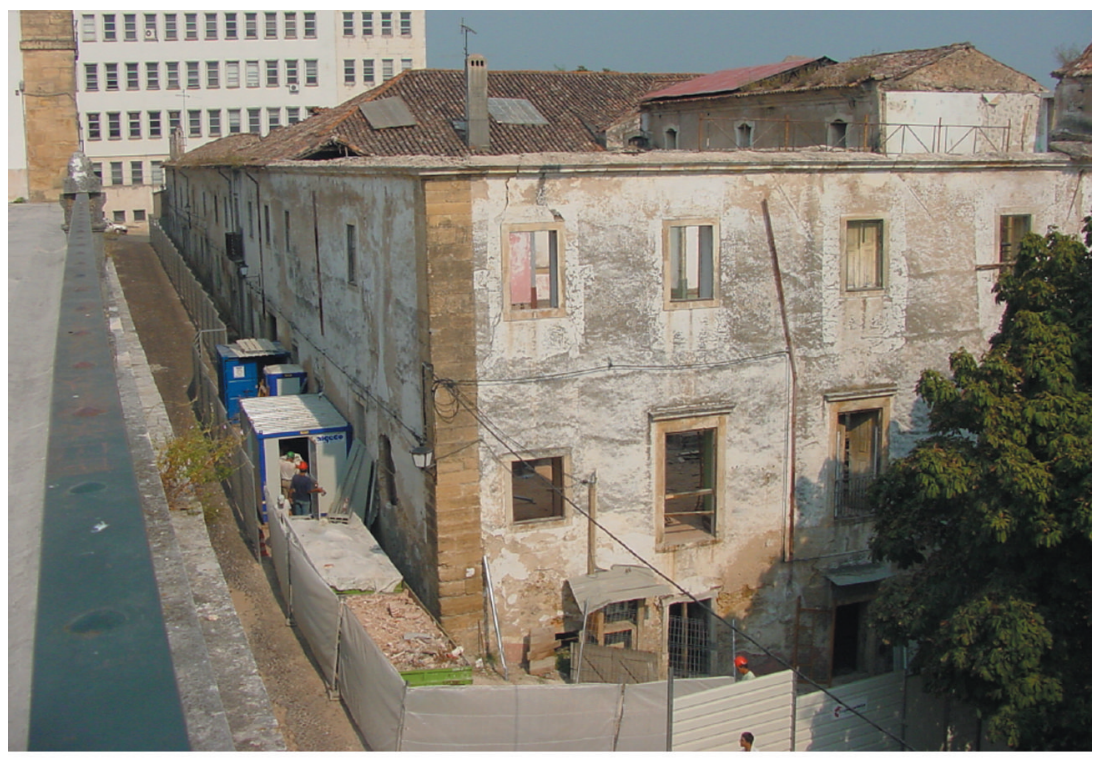

Fото 10 - Quarteirão ocupado pelo Colégio da Trindade

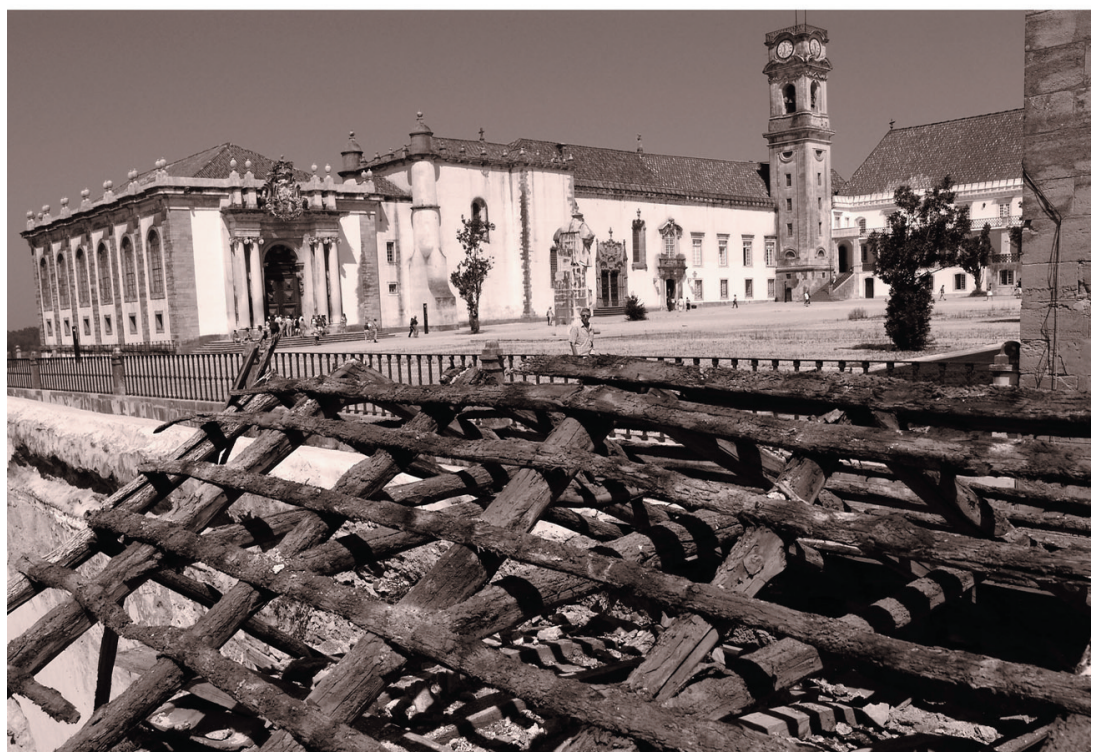

Fото 11 - Perspectiva da intervenção no telhado do Colégio da Trindade 


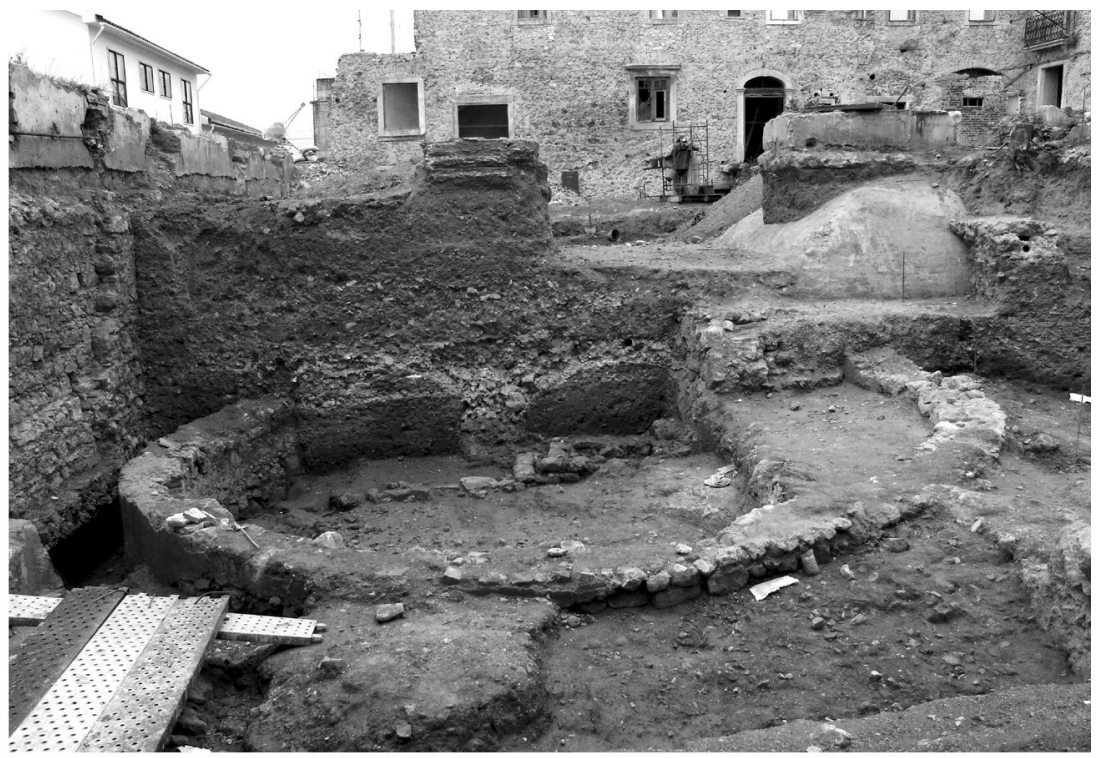

Fото 12 - Estrutura circular, possivelmente relacionada com gestão de água, identificada no decurso dos trabalhos realizados em 2005
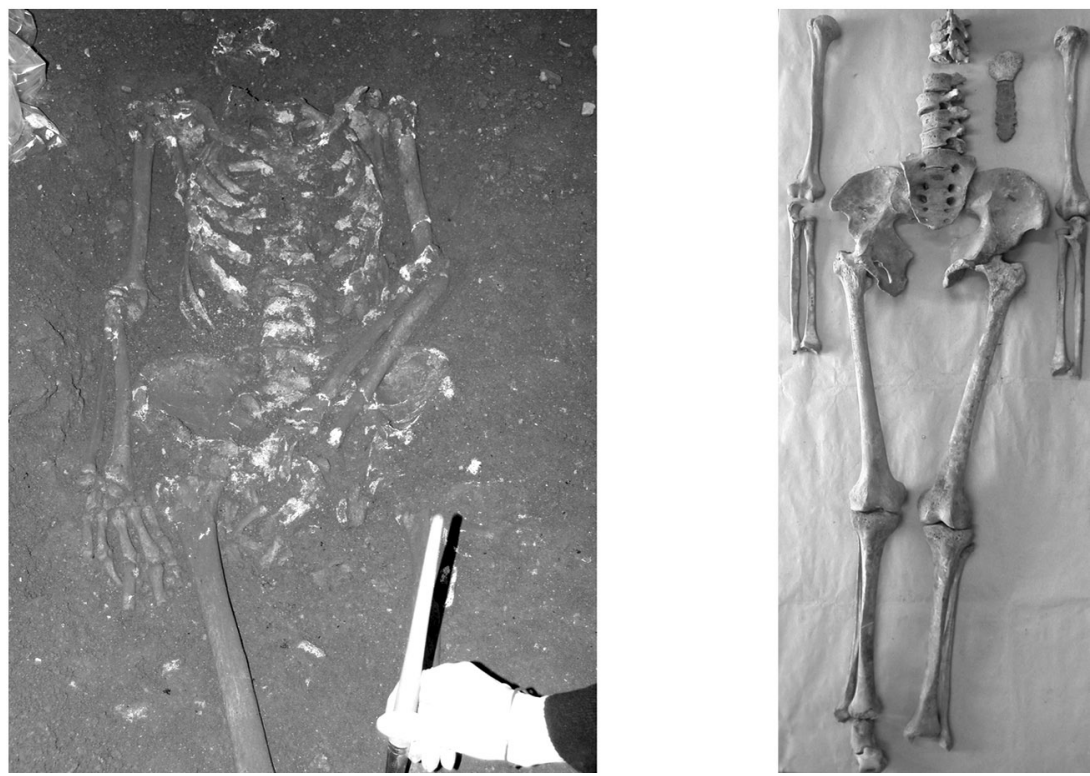

Foто 13 - Trabalhos de antropologia no Colégio da Trindade: campo e gabinete 


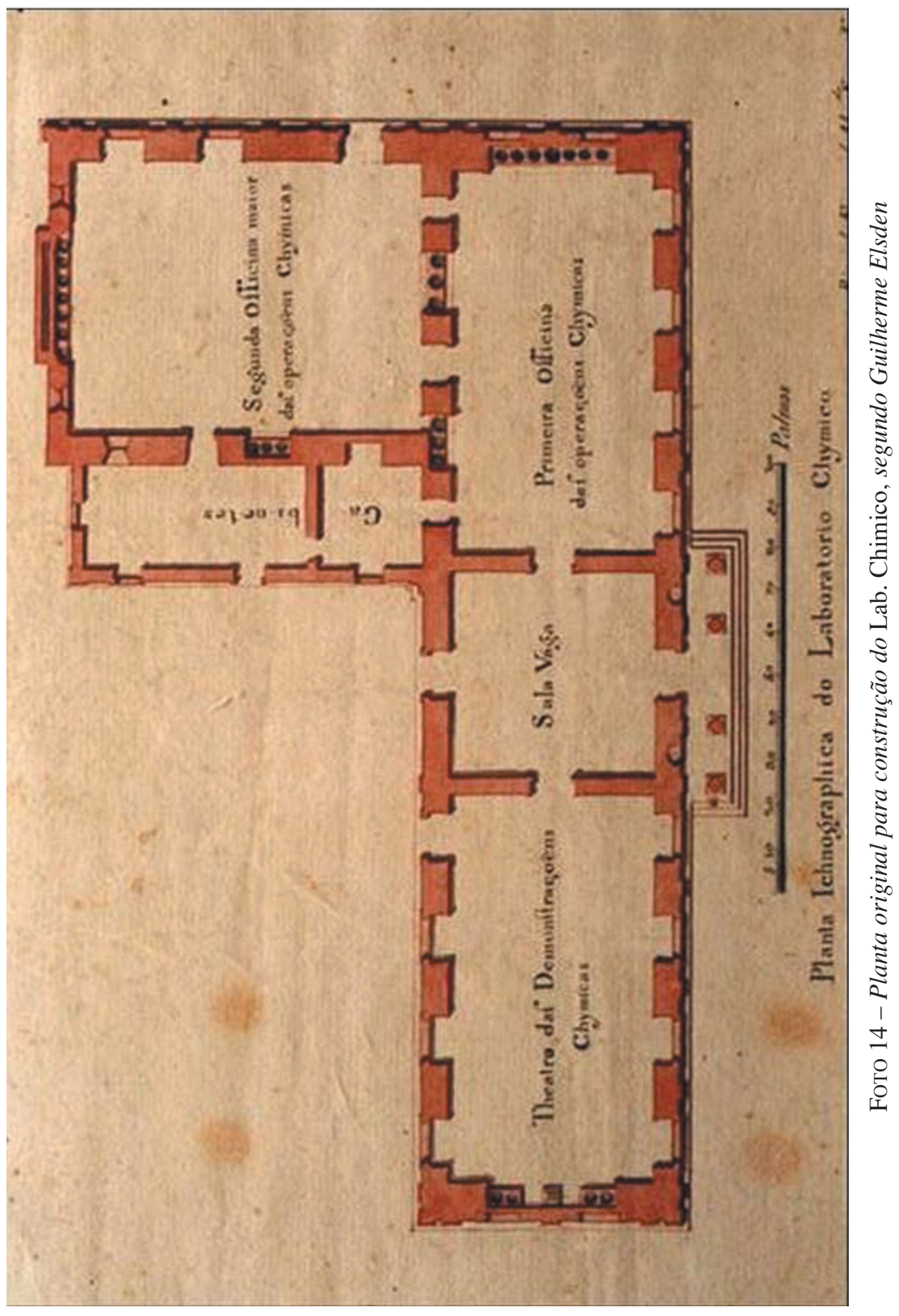




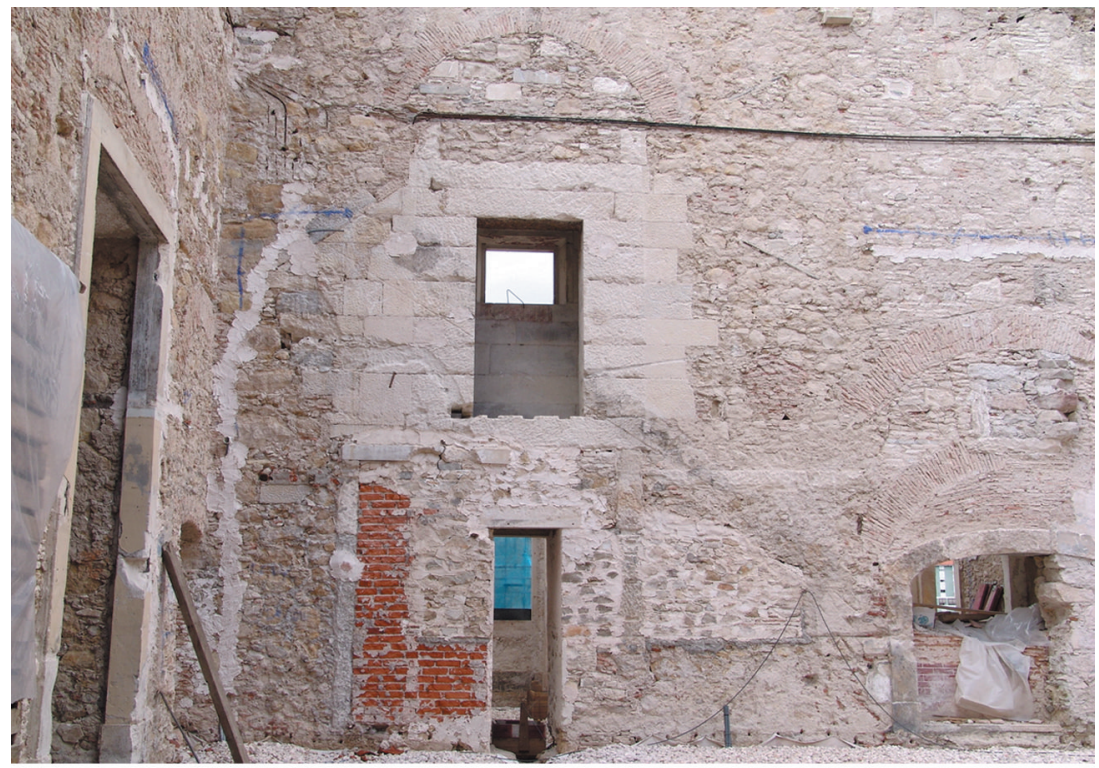

Fото 15 - Pormenor do púlpito do refeitório jesuíta que se encontrava emparedado

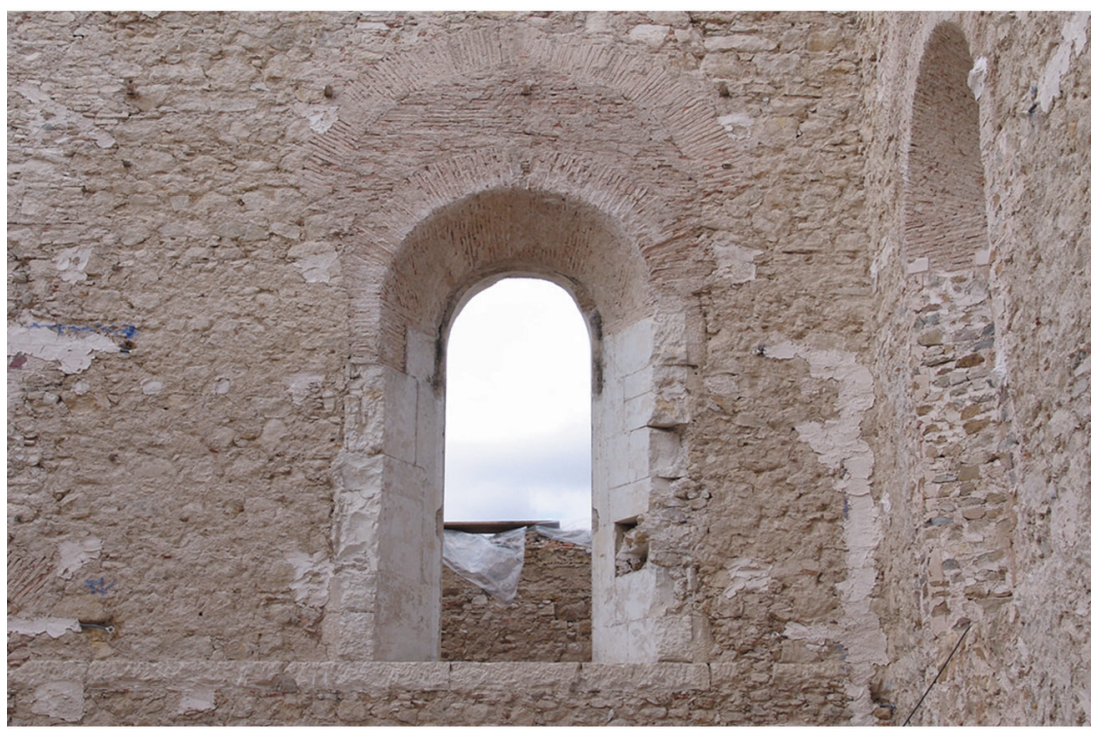

Fото 16 - Perspectiva de uma janela pertencente ao refeitório identificada no decurso dos trabalhos 


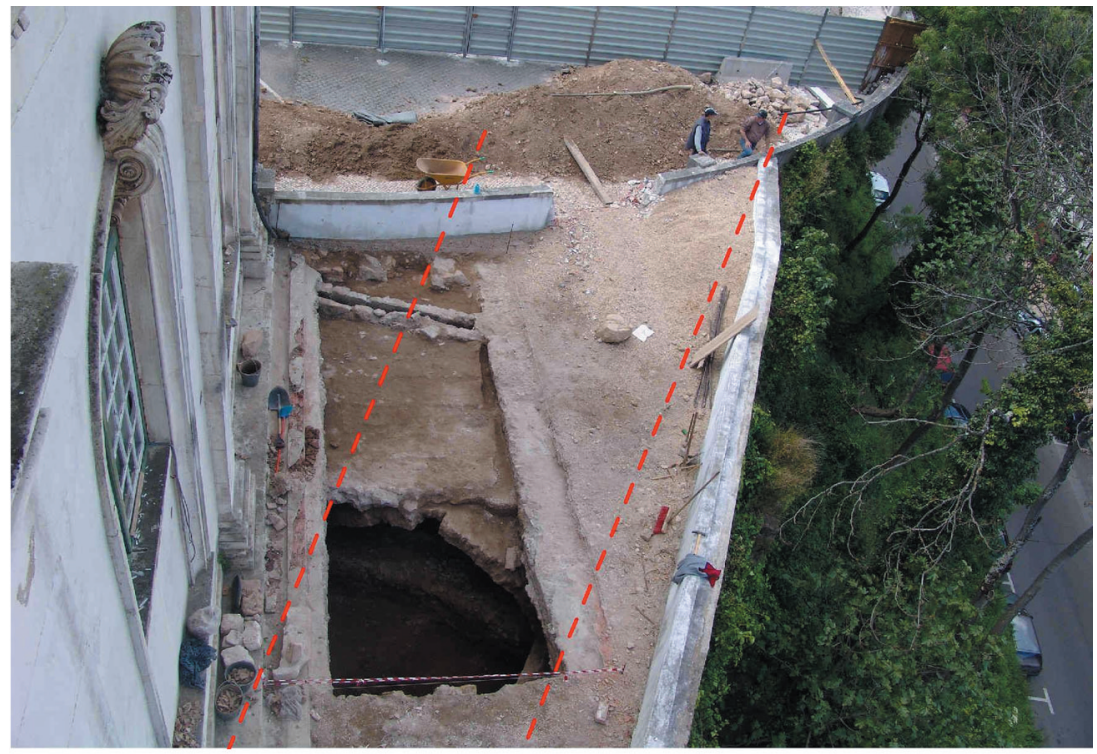

Fото 17 - Implantação da estrutura subterrânea/cisterna no topo norte do laboratório

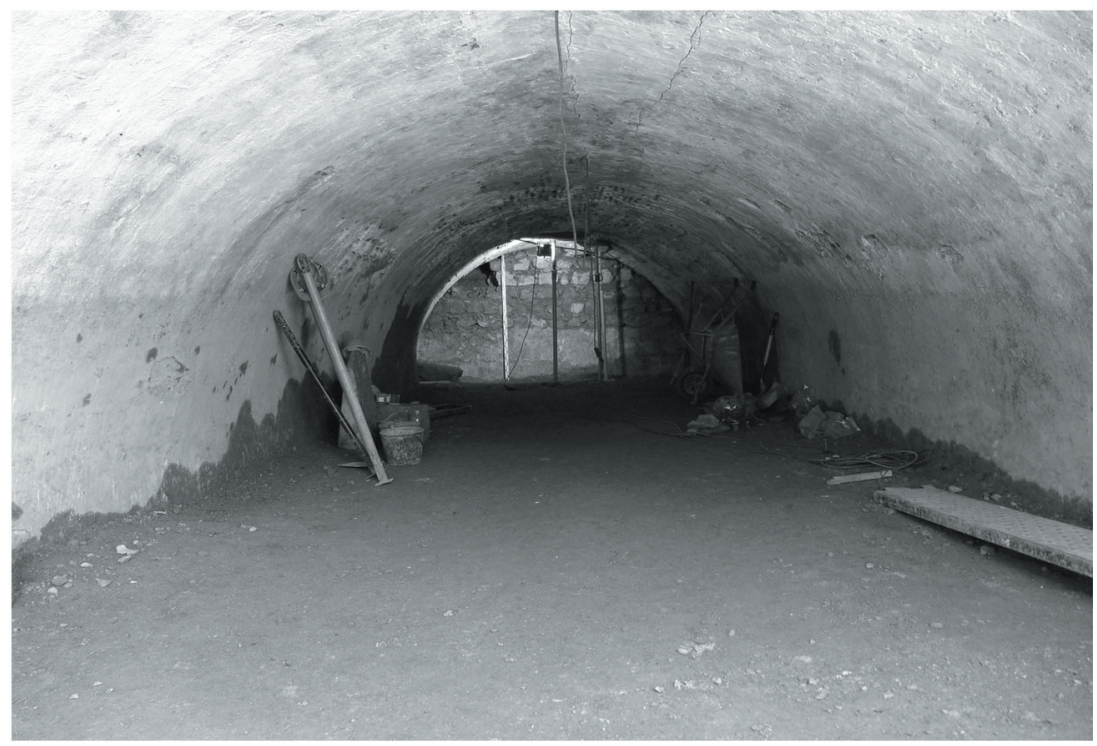

Fото 18 - Perspectiva interior da estrutura subterrânea/cisterna identificada nas escavações 